\title{
The effect of ageing on human lymphocyte subsets: comparison of males and females
}

\author{
Jun Yan ${ }^{1}$, Judith M Greer ${ }^{1}$, Renee Hull ${ }^{3}$, John D O'Sullivan ${ }^{1,3}$, Robert D Henderson ${ }^{1,3}$, Stephen J Read ${ }^{3}$, \\ Pamela A McCombe $1,2,3^{*}$
}

\begin{abstract}
Background: There is reported to be a decline in immune function and an alteration in the frequency of circulating lymphocytes with advancing age. There are also differences in ageing and lifespan between males and females. We performed this study to see if there were differences between males and females in the frequency of the different lymphocyte subsets with age.

Results: Using flow cytometry we have examined different populations of peripheral blood leukocytes purified from healthy subjects with age ranging from the third to the tenth decade. We used linear regression analysis to determine if there is a linear relationship between age and cell frequencies. For the whole group, we find that with age there is a significant decline in the percentage of naïve $T$ cells and $C D 8^{+} T$ cells, and an increase in the percentage of effector memory cells, $\mathrm{CD}^{+}{ }^{\mathrm{foxp}} 3^{+} \mathrm{T}$ cells and NK cells. For all cells where there was an effect of ageing, the slope of the curve was greater for men than for women and this was statistically significant for CD8 ${ }^{+} \alpha \beta^{+}$T cells and $\mathrm{CD}^{+}{ }^{+}$CD45RA CCR7 ${ }^{-}$effector memory cells. There was also a difference for naive cells but this was not significant.
\end{abstract}

Conclusion: The cause of the change in percentage of lymphocyte subsets with age, and the different effects on males and females is not fully understood but warrants further study.

\section{Introduction}

It is known that there is a loss of lymphoid tissue [1] and a decline in the function of the human immune system with increasing age [2-4]. This decline, sometimes termed "immunosenescence" $[5,6]$, has been implicated in the increased susceptibility of aged people to a number of diseases, including cardiovascular disease $[7,8]$, autoimmune disease and malignancy, and to impairment of response to vaccination and infection $[9,10]$. Males have a shorter lifespan than females and thus may be more susceptible to the effects of aging [11]. The immune system of males also has differences from the immune system of females [12,13]. However, little is known about whether males and females show differences in the effects of aging on the immune system. We have been particularly interested in the percentages of cells in peripheral blood in older age groups, because of

\footnotetext{
* Correspondence: Pamela.McCombe@uq.edu.au

${ }^{1}$ The University of Queensland, UQ Centre for Clinical Research, Royal Brisbane \& Women's Hospital, Brisbane, Australia
}

our studies of the peripheral immune response to stroke, [14] which affects an older age group.

Current studies indicate that impaired immune function with age is associated with alterations in cell numbers, and also, in humans and in rats, with decreased $\mathrm{T}$ cell activation and proliferation [15-18]. With ageing in humans there is a decline in the number of naïve cells, an increase in the ratio of memory to naïve cells [4], the number of memory $T$ cells $[19,20]$, and the ratio of $C D 4^{+}$ to $\mathrm{CD} 8^{+}$cells [21] and an increase in the percentage of NK cells [22] although the function of NK cells declines. Less is known about the changes in immunoregulatory $\mathrm{T}$ cells (Treg) with age, but the number of $\mathrm{CD}^{+}{ }^{+}$Treg cells [23-25] and the frequency of $\mathrm{CD}^{+}$Treg cells [26] have been reported to increase with age. However, there are suggestions in mice that $\mathrm{CD} 4^{+} \mathrm{CD} 25^{-}$effector cells become incompetent with age [27].

The mechanisms involved in the decline in immune function with age are not fully understood. These changes are often ascribed to changes in the length of telomeres, although this is controversial [28]. 
Even though $\mathrm{T}$ cells can use telomerase to maintain the length of telomeres during cell proliferation, with ageing there is a reduction of the length of their telomeres due to loss of telomerase activity $[29,30]$. With increasing age, telomerase activity is better preserved in NK cells than in $\mathrm{CD}^{+} \mathrm{T}$ cells [31]. In monkeys, the loss of naïve cells is correlated with loss of telomere length [32]. Other proposed mechanisms of immunosenescence are microsatellite instability due to abnormal DNA repair [33] or to age-related epigenetic changes [34]. It is thought that immunosenescence is a consequence of chronic antigenic stress $[35,36]$. Cytomegalovirus infection appears to contribute to immunosenescence [37] by chronic stimulation and activation of $\mathrm{CD}^{+}$cells [38].

To investigate the effects of age and gender on human lymphocyte populations, we studied lymphocyte subsets and their expression of activation markers in peripheral blood in healthy people above the age of 21 , and analyzed this according to gender.

\section{Subjects and Methods}

\subsection{Subjects and blood collection}

The procedures involved in the study were approved by Royal Brisbane and Women's Hospital Health Service District Office of the Human Research Ethics Committee and The Medical Research Ethics Committee, The University of Queensland, Brisbane, Australia. Blood $(50 \mathrm{ml})$ was collected from healthy volunteers by venipuncture. We regarded subjects as being healthy if they had no acute illness, and were on no medication other than anti-hypertensive medication, and had no serious prior illnesses. We did not investigate whether the subjects had previous infection with Epstein Barr virus or cytomegalovirus. The age and sex distribution of the subjects are summarized in Table 1.

\subsection{Purification of PBL and staining for flow cytometry}

Blood was separated by density gradient centrifugation through LymphoSep (MP Biotechnologies). Peripheral blood leukocytes (PBL) were then isolated and washed twice with PBS containing 1\% supreme serum, counted,

Table 1 Age and sex of participants in the study

\begin{tabular}{llll}
\hline & \multicolumn{3}{c}{ Number of subjects } \\
Age group & Total & Male & Female \\
\hline 20 's & 12 & 5 & 7 \\
30 's & 14 & 7 & 7 \\
40 's & 12 & 6 & 6 \\
50 's & 14 & 7 & 7 \\
60 's & 12 & 6 & 6 \\
70 's & 9 & 3 & 6 \\
$>80$ & 7 & 3 & 4 \\
Total & 80 & 37 & 43 \\
\hline
\end{tabular}

and the concentration of cells $\left(1 \times 10^{7}\right.$ per $\left.\mathrm{ml}\right)$ of suspension was determined. All the data generated by flow cytometry was from freshly purified PBL. Antibodies used for staining were against CD3, CD4, CD8, CD20, CD25, CD45RA, CD69, $\alpha \beta$ TCR, $\gamma \delta$ TCR and CCR7 (all from BD, conjugated either to FITC, PE, PerCP or $\mathrm{APC}$ ) and FoxP3 (from eBioScience, PE-conjugated). Fluorochrome-conjugated isotype-matched antibodies were used as negative controls. For surface staining, PBL $\left(1 \times 10^{6}\right.$ cells in $100 \mu \mathrm{l}$ PBS containing $1 \%$ serum and $0.1 \% \mathrm{NaN}_{3}$ ) were incubated with $1 \mu \mathrm{g}$ antibody in the dark at $4^{\circ} \mathrm{C}$ for $30 \mathrm{~min}$ and then washed twice. For detecting regulatory $\mathrm{T}$ cells, $\mathrm{PBL}$ were firstly incubated with anti-CD4-FITC and anti-CD25-APC antibodies, then were fixed, permeabilized, incubated with antiFoxP3-PE or appropriate isotype control and washed 3 times. Cells were analyzed on a four-colour flow cytometer (FACSCalibur, BD), with gating on the total lymphoid and monocyte populations, as previously described [14]. Samples were obtained and studied individually. For consistency, for each flow cytometry analysis we used the standard calibration beads (BD) to set the forward scatter and side scatter and PMT voltage. The compensation was then adjusted by single staining PBL cells (in particularly, cells from each sample were stained with FITC,/PE/PerCP/APC/Alexa 46 in each experiment). For the experimental samples, a corresponding isotype control was used to set gates, or positive/negative cell populations.

\subsection{Statistical analysis}

To analyse the number of $\mathrm{T}$ cells, $\mathrm{B}$ cells, activated $T$ cells and activated B cells, first we gated on the lymphoid cell population. For naïve, effector or central memory cells, we first gated on the CD3 cell population. CD4/CD8 cell population was gated for analysis of alpha beta TCR/gamma delta TCR cells. For Treg analysis, we gated on the CD4 cell population. To investigate whether there was a linear relationship between age in years and the percentage of cells with different cell surface markers, we performed linear regression analysis. To determine whether there was a statistically significant difference between men and women, we compared the slope of the curves, using Graphpad prism. Data are expressed as the mean \pm S.D. Statistical significance between groups was evaluated using nonparametric Kruskal-Wallis test within One-way ANOVAL in GraphPad. The statistical data was considered as significant if $P<0.05$.

\section{Results}

The results of linear regression analysis for $\mathrm{CD} 3$ ( $\mathrm{T}$ cells/NKT cells), CD20 (B cells) and CD56 (NK/NKT cells) are shown in Figure 1 . In the $\mathrm{CD}^{+}$cells 

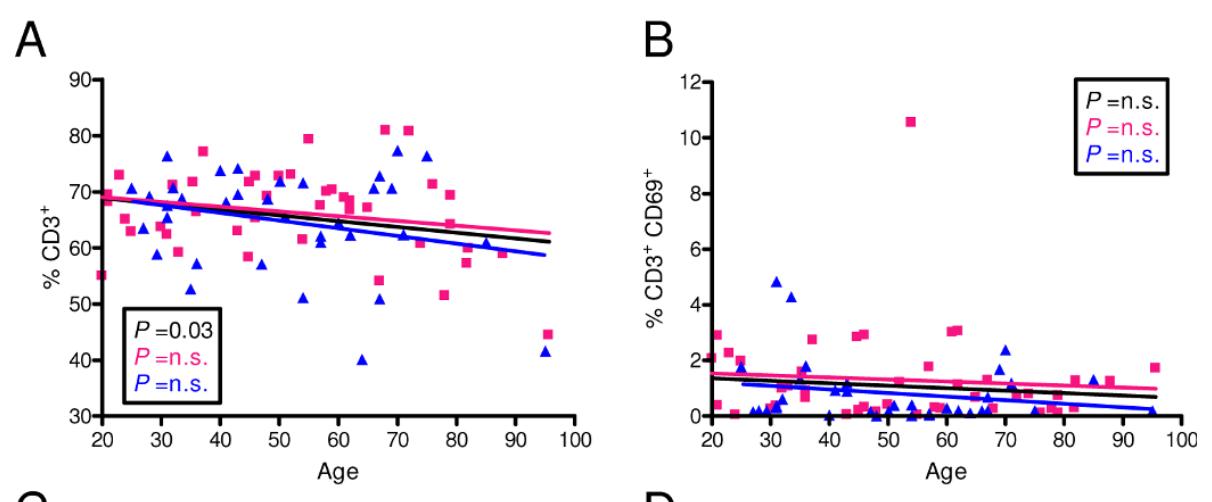

C
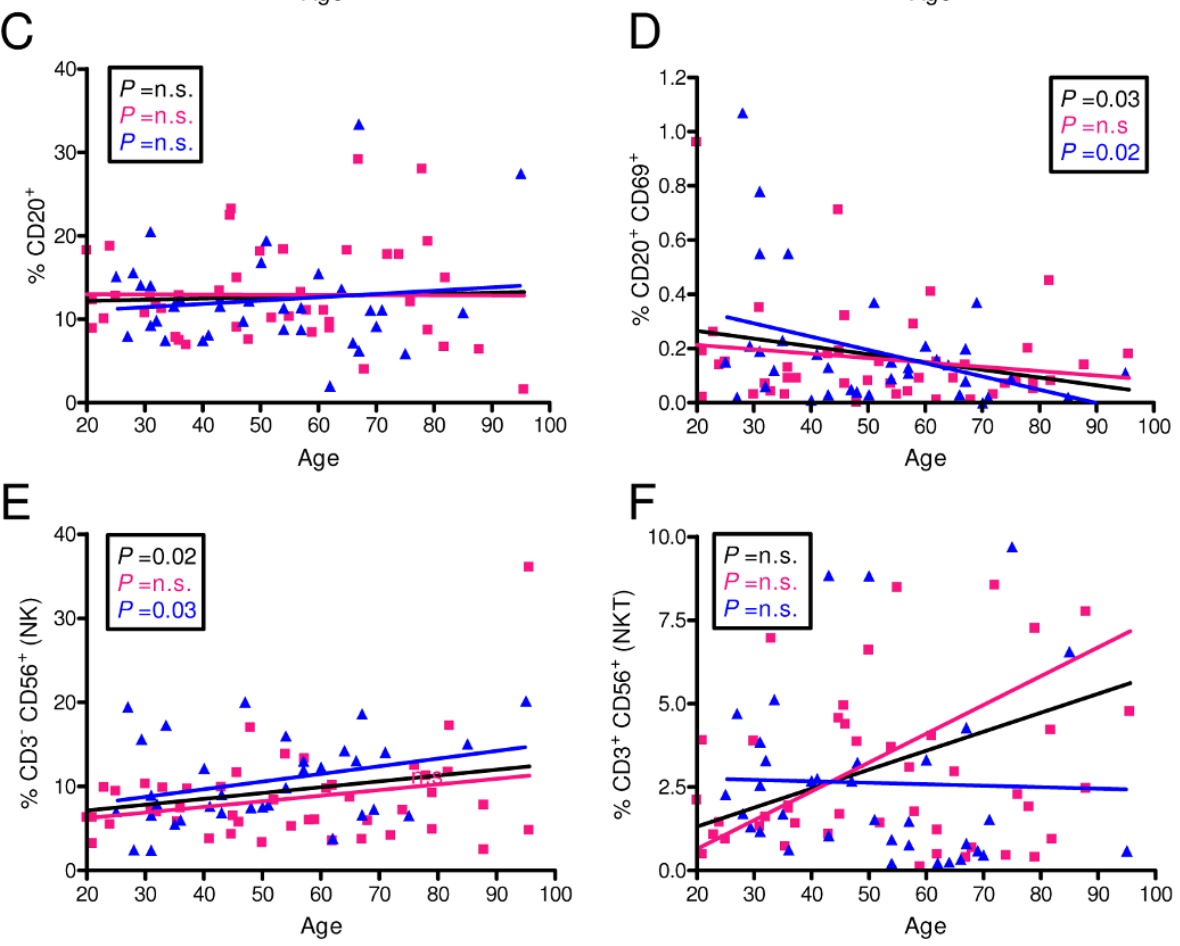

Figure 1 Distribution of percentages of PBL from individuals of different ages bearing different cell markers. The cell markers that PBL were stained for are shown on the $Y$ axis. The linear regression results for all individuals (black line), males (blue line) and females (pink line) and the relevant $P$ values are shown on the graphs. n.s. $=$ not significant.

population (Figure 1A) there was a significant decline in cell frequency that was significant for the combined group of males and females, but not for males and females alone. For the activated $\mathrm{CD}^{+} \mathrm{CD}^{+} 9^{+}$cell population (Figure $1 \mathrm{~B}$ ) and the $\mathrm{CD} 20+\mathrm{B}$ cell population (Figure 1C) there were no significant differences with age. There was a significant decline in the percentage of activated $\mathrm{CD} 9^{+} \mathrm{B}$ cells with age in males, but not females (Figure 1D), and a significant increase in the percentage of NK cells with age in males (Figure 1E). There were no significant changes with age in the NKT cell population (Figure 1F).

When $\mathrm{CD}^{+}$cells were further subdivided into $\mathrm{CD} 4^{+}$ and $\mathrm{CD}^{+} \mathrm{T}$ cells (Figure 2), there were no significant changes in the frequency of $\mathrm{CD}^{+}$cells with age
(Figure 2A). There was a significant decrease in the percentages of $\mathrm{CD}^{+}{ }^{+} \mathrm{CD} 8^{+} \mathrm{T}$ cells in males with aging (Figure $2 \mathrm{~B}$ ), and with aging there was an increase in the ratio of CD4:CD8 $\mathrm{T}$ cells in males (Figure $2 \mathrm{C}$ ).

There was no change in the frequency of activated $\mathrm{CD}^{+} \mathrm{CD} 9^{+}$cells with age (Figure $3 \mathrm{~A}$ ) or of $\mathrm{CD} 8^{+} \mathrm{CD} 69$ ${ }^{+}$cells (Figure 3D). For CD4 ${ }^{+} \mathrm{TCR} \alpha \beta^{+} \mathrm{T}$ cells there was no significant change with age (Figure $3 \mathrm{~B})$ but for $\mathrm{CD}^{+}$ $\mathrm{TCR} \alpha \beta+$ cells there was a significant decline with age that was significant in males but not females (Figure 3E). For TCR $\gamma \delta$ cells there was no significant change with age (Figure $3 \mathrm{c}$ and $3 \mathrm{~F}$ ).

The $\mathrm{CD}^{+}$cells were also subdivided on the basis of CD45RA and CCR7 expression into $\mathrm{CD}^{+} \mathrm{CD} 45 \mathrm{RA}$ ${ }^{+} \mathrm{CCR}^{+}$naïve cells, $\mathrm{CD}^{+}{ }^{+} \mathrm{CD} 45 \mathrm{RA}^{-} \mathrm{CCR} 7^{-}$effector 


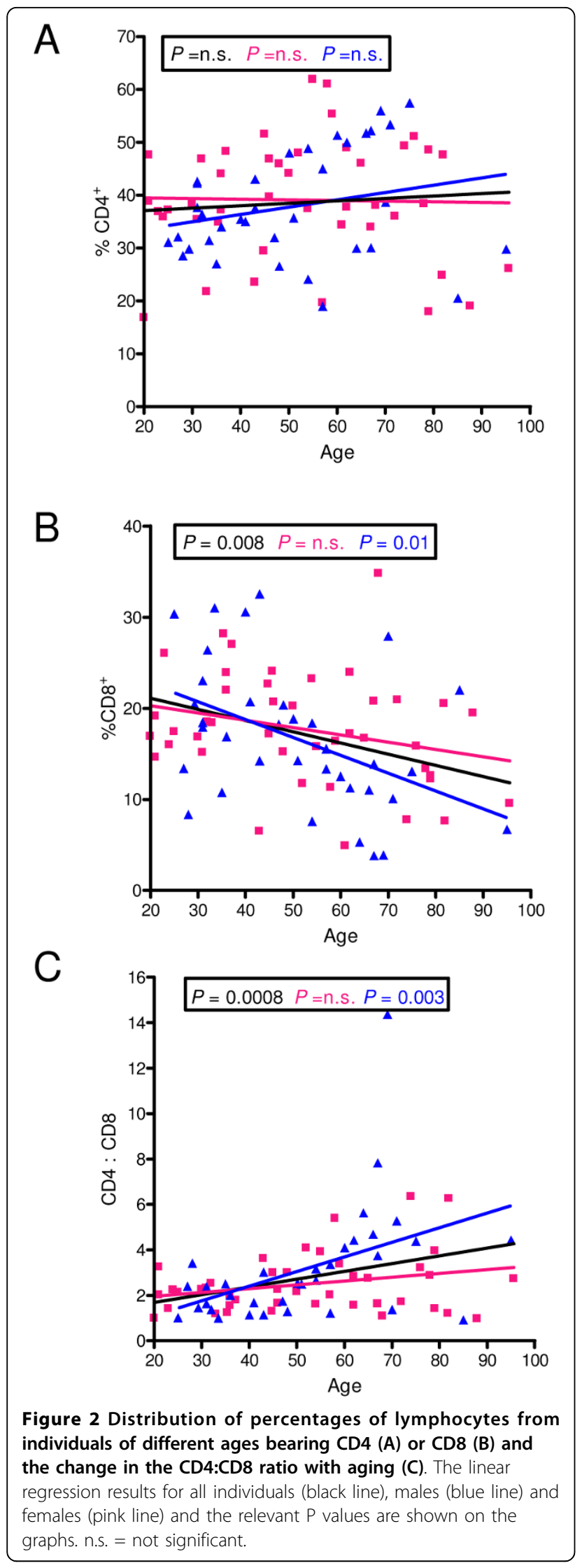

memory cells, central memory cells, and terminally differentiated subtypes (Figure 4). With aging, there was a significant decrease in the naïve population that was significant in males but not females (Figure 4A). There was no significant change with age for effector memory cells (figure 4C). There was a significant increase in effector memory cells with age, and this was highly significant in males but not females (Figure 4B). There was no significant change with age in terminally differentiated cells (Figure 4D).

As shown in Figure 5, we also analyzed $\mathrm{Cd} 3{ }^{+} \mathrm{CD} 4^{+}$cells on the basis of expression of CD25 and Foxp3. Foxp3 is a marker of regulatory $\mathrm{T}$ cells (Treg cells), but also appears to be increased transiently in most activated human $\mathrm{CD}^{+}{ }^{+} \mathrm{T}$ cells $[39,40]$. When $\mathrm{CD} 4^{+} \mathrm{T}$ cells were analyzed, there was a no significant change with age in the percentage of cells expressing Foxp3 (Figure 5A), nor in the percentage of cell that were CD2 $5^{\text {hi }}$ or the percentage of CD25 ${ }^{\text {hi }}$ cells that were CD $25^{\text {hi }}$ Foxp $3^{+}$, suggesting that the percentage of Treg cells does not change markedly with age.

To compare the effects of aging in males and females, we directly compared the slopes of the curves for males and females. This is shown in Table 2. There were significant differences in the slopes of the curves for the $\mathrm{CD}^{+}$: $\mathrm{CD}^{+}$ratio, for $\mathrm{CD}^{+} \alpha \beta^{+} \mathrm{T}$ cells and central memory cells, as shown in Table 2 .

\section{Discussion}

Ageing is known to have effects on immune function and on the percentages of circulating lymphocytes. Ageing has different effects in males and females with males having a shorter life-span than females [11], so we have investigated whether males and females show different effects of ageing in human peripheral blood lymphocytes. In this study we did not address the functional capacity of these cells. We examined the effects of age on $\mathrm{CD}^{+}$lymphocytes expressing CD4, CD8, CD69, CCR7, CD45RA and CCR7, on CD20 B cells, on T regulatory cells, defined by expression of CD25 and foxp3, and on NK cells. The older subjects were healthy in having no active diseases and having no serious previous illnesses. We did not perform serology to estimate prior exposure to CMV or EBV, although we note that chronic infection with these viruses has been proposed to play a role in immunosenescence [41] and that very old subjects have large numbers of $\mathrm{T}$ cells reactive with CMV [42].

By linear regression analysis we found no significant changes in the percentage of $\mathrm{CD}^{+} \mathrm{T}$ cells or $\mathrm{CD} 20^{+} \mathrm{B}$ cells with age, although we did find a significant decrease in activated $B$ cells with age in males. In mice there is known to be a reduction in production of $B$ cells with aging [43] although this is compensated in 


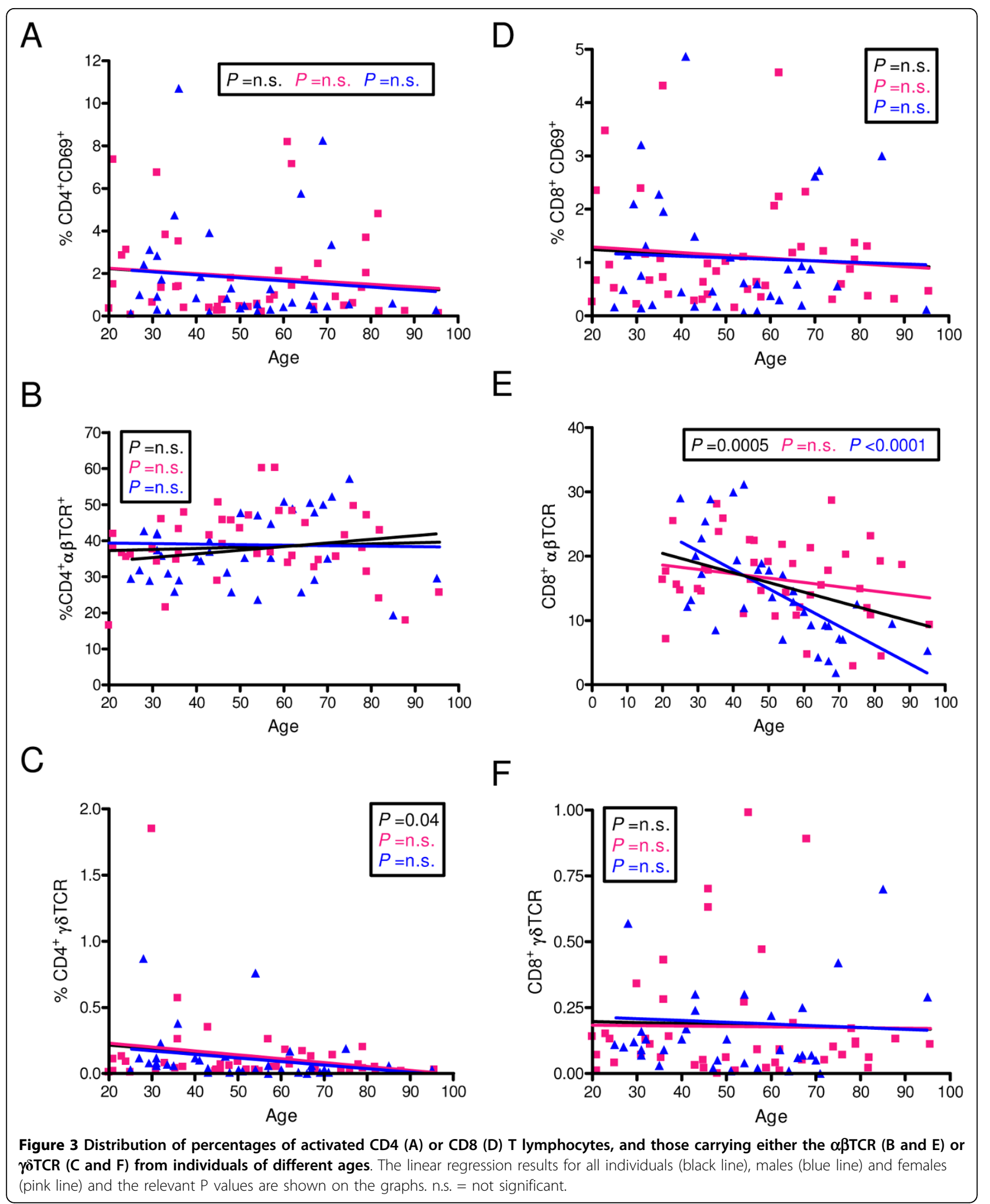




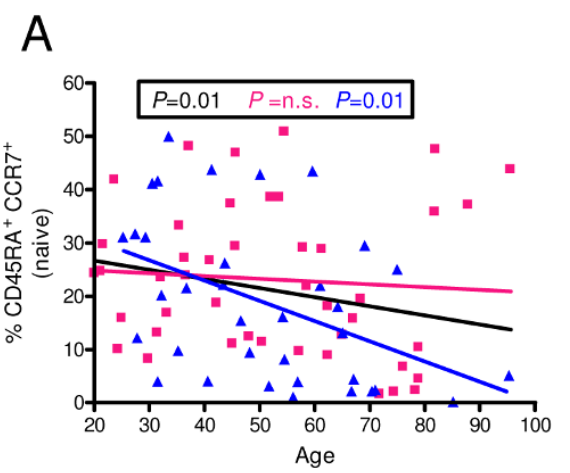

B

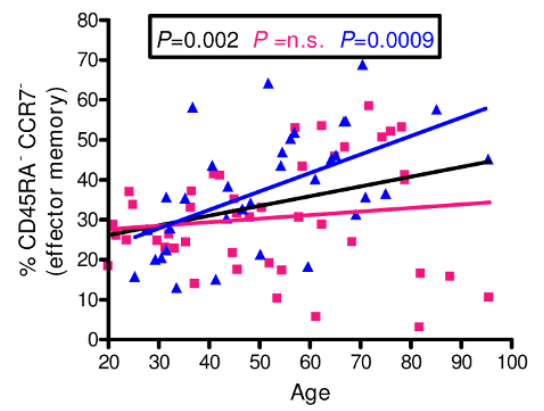

C

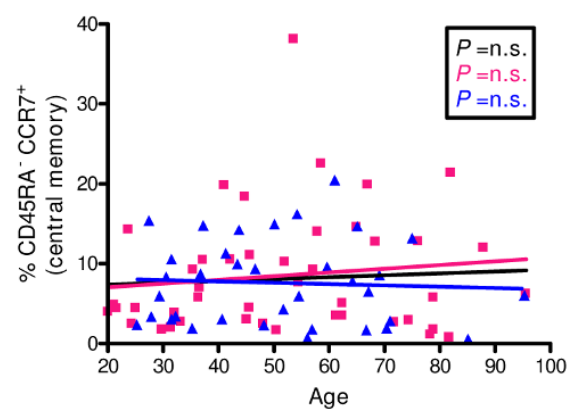

D

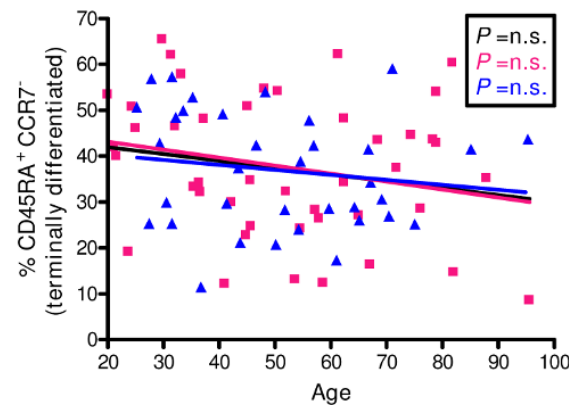

Figure 4 Distribution of percentages of naïve $\left(C D 45 R A^{+} C C R 7^{+}\right)(A)$, effector memory (CD45RA $\left.{ }^{-} C C R 7^{-}\right)(B)$, central memory $(C D 45 R A$ $\mathrm{CCR7}^{+}$) (C), or terminally differentiated (CD45RA ${ }^{+} \mathrm{CCR7}{ }^{-}$) (D) $\mathrm{CD3}^{+}$cells from individuals of different ages. The linear regression results for all individuals (black line), males (blue line) and females (pink line) and the relevant $\mathrm{P}$ values are shown on the graphs. n.s. = not significant.

part by increased lifespan of B cells [44-46]. The agerelated impairment of $B$ cell development is associated with impaired V-DJ heavy chain gene recombination $[47,48]$ and also related with changes in the expression and activity of the basic helix-loop-helix proteins E2Aencoded E12 and E47 transcription factors, which help the expression of immunoglobulin heavy chain by binding to the immunoglobulin heavy chain enhancer.

We found an increase in the proportion of NK cells. This is also consistent with previous studies [22] that find increased numbers but reduced functional capacity of NK cells. There are reports of increased NK cells in bone marrow, and indeed these cells are thought to contribute to a decrease in $\mathrm{B}$ cell precursors in old age, by inhibiting E2A protein and E47 transcription factors [49]. It has been suggested that ageing is a state when the innate immune system prevails over the adaptive immune system. However, there is also a decline in NK cell activity, seen also in rats, which is more pronounced in males than females [18].

There was no significant change in the percentage of $\mathrm{CD}^{+}$cells but there was a decline in the percentage of $\mathrm{CD}^{+}$cells and an increase in the ratio of CD4:CD8 cells, as has been previously reported [21]. The decline in $\mathrm{CD}^{+}$cells was more apparent in the TCR $\alpha \beta$ than in the TCR $\delta \gamma$ subsets. There was a significant decline in the percentage of $\mathrm{CD}^{+} \mathrm{CD} 45 \mathrm{RA}^{+} \mathrm{CCR} 7^{+}$naïve cells and an increase in the percentage of $\mathrm{CD}^{+} \mathrm{CD}^{+} 5 \mathrm{RA}^{-} \mathrm{CCR} 7^{-}$ effector memory cells with age. The increase in effector memory cells has been suggested to be due in part to chronic antigenic stimulation [38,50].

We also studied T regulatory cells. Previously these cells have been identified as $\mathrm{CD} 4^{+} \mathrm{CD} 25^{\text {hi }}$ according to high constitutive surface expression of interleukin 2 receptor alpha chain CD25 on $\mathrm{CD}^{+}{ }^{+} \mathrm{T}$ cells $[51,52]$. Recently transcription factor Foxp3 has been recognized as the most specific marker of $\mathrm{T}$ regulatory cells [53,54], although Foxp3 also appears to be increased in most activated human $\mathrm{CD}^{+} \mathrm{T}$ cells $[39,40]$. We measured the $\mathrm{CD} 4^{+} \mathrm{CD} 25^{\text {hi }}$ Foxp $3^{+}$cells, CD $4^{+} \mathrm{CD} 25^{\text {hi }}$ cells and $\mathrm{CD} 4^{+} \mathrm{CD} 25^{\text {hi }}$ foxp $3^{+}$cells, and found that although the percentages of Foxp $3^{+}$cells increased with age in the total $\mathrm{CD} 4^{+}$population, there were no significant changes in the percentage of $C D 4^{+} \mathrm{T}$ cells that were both CD25 $5^{\text {hi }}$ and Foxp $3^{+}$with age. In humans, some previous studies have found an increase in Treg cells with age $[23,24]$. Others have found increased $\mathrm{CD} 4{ }^{+} \mathrm{CD} 25^{+}$cells with age, but no increase in $\mathrm{CD} 4{ }^{+} \mathrm{CD} 25^{\mathrm{hi}}$ cells with age, and attributed the increase in $\mathrm{CD} 4{ }^{+} \mathrm{CD} 25^{+}$cells to an increase in cells with intermediate rather than high levels of expression of CD25 [25]. We did not measure the functional capacity of these cells, and acknowledge 


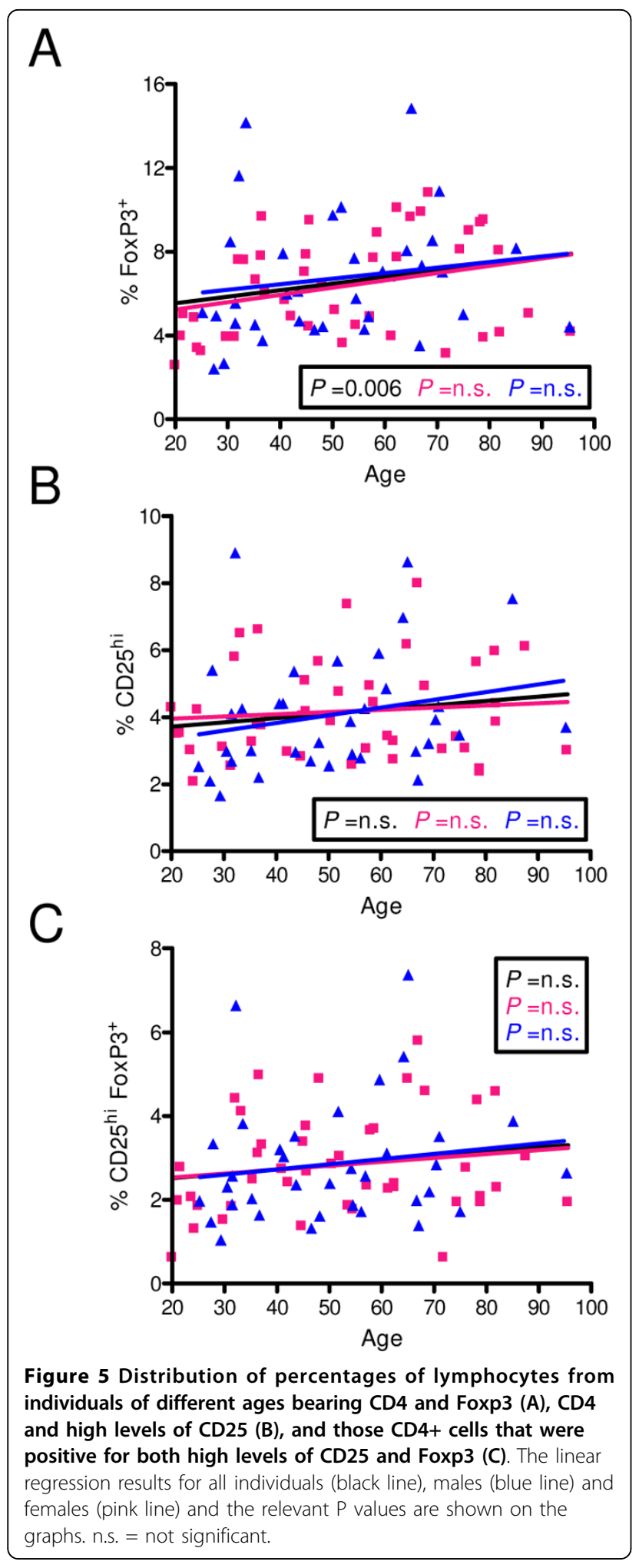

that there are studies showing that the functional capacity of human $\mathrm{CD} 4^{+}$Treg cells declines with age [55].

The reason for gender differences in immunosenescence are a matter for speculation. There are known to be gender differences in the immune system of males and females. In males the total lymphocyte count is similar to that in females but the percentage of $\mathrm{T}$ cells within the lymphocyte population is lower [56,57]. There are differences in the function of the immune system in males and females [12,13], and this is probably contributes to the different ability of males and females to deal with infections, and the different prevalence of autoimmune disease in males and females [58]. Generally, females produce more vigorous humoral and cellular immune responses than males $[59,60]$, shown in mice as an augmented responses to different antigens [61], ability to reject allografts more rapidly that males [62], and in mice and humans by better in vitro responses to mitogens $[60,63]$ and relative resistance to the induction of immune tolerance [64] There is a superior ability of female mice to combat various infections, including with Leishmania and amebic infection with liver abscess [65], which is thought to be due to due to sex difference in Th1 and Th2 responses [66]. Moreover, in Wistar rats infected with Trypanasoma cruzi, there is less parasitaemia in females than males [67].

In the current study we are looking at the differences in immunosenescence between males and females. The changes that we observed with ageing were more apparent in males, although this was statistically significant only for $\mathrm{CD}^{+}$alpha beta $\mathrm{T}$ cells and for effector memory cells. This observation of gender differences in ageing in the immune system is not unique to the immune system. In the heart, there is loss of myocardial mass in men but not in women [68]. Loss of volume in the brain with ageing occurs to a greater extent in men than in women [69]. We note that in all animal species there are gender differences in the effects of ageing, and for humans and for species with species with XY chromosomes, ageing had greater effects in males [11]. Some of this may be due to the effects of hormones. For example, estrogen stimulates c-myc which stimulates telomerase, which could have an anti-ageing effect [70]. Another recent theory relates to the possibility that the evolutionary needs of females and males are different and that mitochondria are better adapted to females than males cells [71]. Our study suggests that there can be differences in immunosenescence between males and females and that this is worth further study. 
Table 2 Comparison of results of linear regression analysis of male and female subjects

\begin{tabular}{|c|c|c|c|}
\hline & & Best fit values & Are lines different? \\
\hline & Female & Male & $p=$ \\
\hline$\overline{C D 4}$ & $-0.01286 \pm 0.08489$ & $0.1511 \pm 0.09574$ & 0.209 \\
\hline CD8 & $-0.08004 \pm 0.04473$ & $-0.2004 \pm 0.06368$ & 0.119 \\
\hline CD4:CD8 & $0.01671 \pm 0.009527$ & $0.06488 \pm 0.02034$ & $0.025^{*}$ \\
\hline CD4CD69 & $-0.01249 \pm 0.01596$ & $-0.01146 \pm 0.02153$ & 0.969 \\
\hline$C D 4 \alpha \beta T C R$ & $-0.01396 \pm 0.07185$ & $0.1150 \pm 0.09017$ & 0.265 \\
\hline $\mathrm{CD} 4 \gamma \delta \mathrm{TCR}$ & $-0.002933 \pm 0.002135$ & $-0.002525 \pm 0.001673$ & 0.8877 \\
\hline CD8CD69 & $-0.005258 \pm 0.007774$ & $-0.001859 \pm 0.01032$ & 0.7908 \\
\hline CD $8 \alpha \beta T C R$ & $-0.06798 \pm 0.04533$ & $-0.2926 \pm 0.05329$ & $0.002^{*}$ \\
\hline CD8 $8 \delta \mathrm{TCR}$ & $-0.0001585 \pm 0.001757$ & $-0.0002358 \pm 0.002729$ & 0.9803 \\
\hline CD20 & $-0.002255 \pm 0.04478$ & $0.02262 \pm 0.03418$ & 0.4128 \\
\hline CD20CD69 & $-0.001613 \pm 0.001390$ & $-0.004036 \pm 0.001982$ & 0.3102 \\
\hline CD3 & $-0.08411 \pm 0.05615$ & $-0.1377 \pm 0.07982$ & 0.5768 \\
\hline CD3CD69 & $-0.007351 \pm 0.01303$ & $-0.01537 \pm 0.01006$ & 0.6483 \\
\hline Naïve & $-0.05219 \pm 0.1052$ & $-0.3391 \pm 0.1251$ & 0.0847 \\
\hline terminal differentiation & $-0.1740 \pm 0.1124$ & $-0.1705 \pm 0.1217$ & 0.9837 \\
\hline effector memory & $0.08792 \pm 0.1042$ & $0.4715 \pm 0.1100$ & $0.0156^{*}$ \\
\hline central memory & $0.04627 \pm 0.05656$ & $0.002732 \pm 0.04994$ & 0.5846 \\
\hline $\mathrm{CD} 4^{+} \mathrm{CD} 25^{\mathrm{hi}}$ & $0.006544 \pm 0.01064$ & $0.01096 \pm 0.01729$ & 0.8217 \\
\hline CD25 ${ }^{\text {hi }}$ Foxp3 & $0.009368 \pm 0.009073$ & $0.001000 \pm 0.01449$ & 0.6129 \\
\hline CD4 ${ }^{+}$Foxp3 & $0.03464 \pm 0.01714$ & $0.03181 \pm 0.02767$ & 0.9281 \\
\hline CD25Foxp3 & $0.003791 \pm 0.006090$ & $-0.01047 \pm 0.01352$ & 0.3054 \\
\hline $\mathrm{CD}^{-} \mathrm{CD} 6^{+}$ & $0.06688 \pm 0.03635$ & $0.07099 \pm 0.04662$ & 0.9454 \\
\hline $\mathrm{CD}^{+} \mathrm{CD}_{56}{ }^{+}$ & $0.08633 \pm 0.03592$ & $-0.001413 \pm 0.02298$ & 0.073 \\
\hline
\end{tabular}

Asterisks denote statistically significant results

\section{Acknowledgements}

We are grateful for the support of the Wesley Research Institute and the National Heart Foundation.

\section{Author details}

'The University of Queensland, UQ Centre for Clinical Research, Royal Brisbane \& Women's Hospital, Brisbane, Australia. ${ }^{2}$ Wesley Research Institute, Wesley Hospital, Brisbane, Australia. ${ }^{3}$ Department of Neurology, Royal Brisbane and Women's Hospital, Brisbane, Australia.

\section{Authors' contributions}

JY performed the analysis, JG supervised the FACS analysis, RH was responsible for recruiting and consenting subjects, JO, RH and SR contributed to the recruitment of subjects and to the development of the study, PM has overall responsibility for the project and for writing the paper. All authors read and approved the final manuscript.

\section{Competing interests}

The authors declare that they have no competing interests.

Received: 13 January 2010 Accepted: 16 March 2010 Published: 16 March 2010

\section{References}

1. Pan WR, Suami H, Taylor Gl: Senile changes in human lymph nodes. Lymphat Res Biol 2008, 6:77-83.

2. Miller RA: Aging and immune function. Int Rev Cytol 1991, 124:187-215.

3. Linton PJ, Dorshkind K: Age-related changes in lymphocyte development and function. Nat Immunol 2004, 5:133-139.

4. Gruver AL, Hudson LL, Sempowski GD: Immunosenescence of ageing. J Pathol 2007, 211:144-156.

5. Pawelec G, Solana R: Immunosenescence. Immunol Today 1997, 18:514-516.
6. Dorshkind K, Swain S: Age-associated declines in immune system development and function: causes, consequences, and reversal. Curr Opin Immunol 2009, 21:404-407.

7. Stern S, Behar S, Gottlieb S: Cardiology patient pages. Aging and diseases of the heart. Circulation 2003, 108:e99-101.

8. McEniery CM, Yasmin, McDonnell B, Munnery M, Wallace SM, Rowe CV, Cockcroft JR, Wilkinson IB: Central pressure: variability and impact of cardiovascular risk factors: the Anglo-Cardiff Collaborative Trial II. Hypertension 2008, 51:1476-1482.

9. Grubeck-Loebenstein B, Della BS, lorio AM, Michel JP, Pawelec G, Solana R: Immunosenescence and vaccine failure in the elderly. Aging Clin Exp Res 2009, 21:201-209.

10. McElhaney JE, Effros RB: Immunosenescence: what does it mean to health outcomes in older adults? Curr Opin Immunol 2009, 21:418-424.

11. Tower J, Arbeitman M: The genetics of gender and life span. J Biol 2009, 8:38.

12. McCombe PA, Greer JM, Mackay IR: Sexual dimorphism in autoimmune disease. Current Molecular Medicine 2009.

13. Nunn $\mathrm{CL}$, Lindenfors $P$, Pursall $E R$, Rolff J: On sexual dimorphism in immune function. Philos Trans R Soc Lond B Biol Sci 2009, 364:61-69.

14. Yan J, Greer JM, Etherington K, Cadigan GP, Cavanagh H, Henderson RD, O'sullivan JD, Pandian JD, Read SJ, McCombe PA: Immune activation in the peripheral blood of patients with acute ischemic stroke. J Neuroimmunol 2009, 206:112-117.

15. Miller RA: Effect of aging on T lymphocyte activation. Vaccine 2000, 18:1654-1660.

16. Douziech N, Seres I, Larbi A, Szikszay E, Roy PM, Arcand M, Dupuis G, Fulop T Jr: Modulation of human lymphocyte proliferative response with aging. Exp Gerontol 2002, 37:369-387.

17. Jiang J, Gross D, Elbaum P, Murasko DM: Aging affects initiation and continuation of T cell proliferation. Mech Ageing Dev 2007, 128:332-339.

18. De la Fuente M, Baeza I, Guayerbas N, Puerto M, Castillo C, Salazar V, Ariznavarreta $C$, Tresguerres JA: Changes with ageing in several leukocyte functions of male and female rats. Biogerontology 2004, 5:389-400. 
19. Hong MS, Dan JM, Choi JY, Kang I: Age-associated changes in the frequency of naive, memory and effector CD8+ T cells. Mech Ageing Dev 2004, 125:615-618.

20. Saule P, Trauet J, Dutriez V, Lekeux V, Dessaint JP, Labalette M: Accumulation of memory $T$ cells from childhood to old age: central and effector memory cells in CD4(+) versus effector memory and terminally differentiated memory cells in CD8(+) compartment. Mech Ageing Dev 2006, 127:274-281

21. Amadori A, Zamarchi R, De SG, Forza G, Cavatton G, Danieli GA, Clementi M, Chieco-Bianchi L: Genetic control of the CD4/CD8 T-cell ratio in humans. Nat Med 1995, 1:1279-1283.

22. Facchini A, Mariani E, Mariani AR, Papa S, Vitale M, Manzoli FA: Increased number of circulating Leu 11+ (CD 16) large granular lymphocytes and decreased NK activity during human ageing. Clin Exp Immunol 1987, 68:340-347.

23. Gregg R, Smith CM, Clark FJ, Dunnion D, Khan N, Chakraverty R, Nayak L, Moss PA: The number of human peripheral blood CD4+ CD25high regulatory T cells increases with age. Clin Exp Immunol 2005, 140:540-546.

24. Trzonkowski $P$, Szmit E, Mysliwska J, Mysliwski A: CD4+CD25+ T regulatory cells inhibit cytotoxic activity of CTL and NK cells in humans-impact of immunosenescence. Clin Immunol 2006, 119:307-316.

25. Brusko TM, Hulme MA, Myhr CB, Haller MJ, Atkinson MA: Assessing the in vitro suppressive capacity of regulatory T cells. Immunol Invest 2007, 36:607-628.

26. Simone R, Zicca A, Saverino D: The frequency of regulatory CD3+CD8+. J Leukoc Biol 2008, 84:1454-1461.

27. Nishioka T, Shimizu J, lida R, Yamazaki S, Sakaguchi S: CD4+CD25+Foxp3+ T cells and CD4+CD25-Foxp3+ T cells in aged mice. J Immunol 2006, 176:6586-6593.

28. Miller RA: Telomere diminution as a cause of immune failure in old age: an unfashionable demurral. Biochem Soc Trans 2000, 28:241-245.

29. lancu EM, Speiser DE, Rufer N: Assessing ageing of individual T lymphocytes: Mission impossible? Mech Ageing Dev 2007.

30. Goronzy JJ, Fujii H, Weyand CM: Telomeres, immune aging and autoimmunity. Exp Gerontol 2006, 41:246-251.

31. Mariani E, Meneghetti A, Formentini I, Neri S, Cattini L, Ravaglia G, Forti P, Facchini A: Different rates of telomere shortening and telomerase activity reduction in CD8 T and CD16 NK lymphocytes with ageing. Exp Gerontol 2003, 38:653-659.

32. Lee WW, Nam KH, Terao K, Yoshikawa Y: Age-related telomere length dynamics in peripheral blood mononuclear cells of healthy cynomolgus monkeys measured by Flow FISH. Immunology 2002, 105:458-465.

33. Neri S, Pawelec G, Facchini A, Ferrari C, Mariani E: Altered expression of mismatch repair proteins associated with acquisition of microsatellite instability in a clonal model of human T lymphocyte aging. Rejuvenation Res 2008, 11:565-572

34. Issa JP: Age-related epigenetic changes and the immune system. Clin Immunol 2003, 109:103-108.

35. Franceschi C, Valensin S, Fagnoni F, Barbi C, Bonafe M: Biomarkers of immunosenescence within an evolutionary perspective: the challenge of heterogeneity and the role of antigenic load. Exp Gerontol 1999, 34:911-921.

36. Mazzatti DJ, White A, Forsey RJ, Powell JR, Pawelec G: Gene expression changes in longterm culture of T-cell clones: genomic effects of chronic antigenic stress in aging and immunosenescence. Aging Cell 2007, 6:155-163.

37. Koch S, Larbi A, Ozcelik D, Solana R, Gouttefangeas C, Attig S, Wikby A, Strindhall J, Franceschi C, Pawelec G: Cytomegalovirus infection: a driving force in human T cell immunosenescence. Ann N Y Acad Sci 2007 1114:23-35.

38. Pita-Lopez ML, Gayoso I, Delarosa O, Casado JG, Alonso C, MunozGomariz E, Tarazona R, Solana R: Effect of ageing on CMV-specific CD8 T cells from CMV seropositive healthy donors. Immun Ageing 2009, 6:11.

39. Morgan ME, van Bilsen JH, Bakker AM, Heemskerk B, Schilham MW, Hartgers FC, Elferink BG, van der ZL, de Vries RR, Huizinga TW, Ottenhoff $T H$ Toes RE: Expression of FOXP3 mRNA is not confined to CD4+CD25+ T regulatory cells in humans. Hum Immunol 2005, 66:13-20.

40. Wang J, loan-Facsinay A, van d V, Huizinga TW, Toes RE: Transient expression of FOXP3 in human activated nonregulatory CD4+ T cells. Eur J Immunol 2007, 37:129-138.
41. Vescovini R, Telera A, Fagnoni FF, Biasini C, Medici MC, Valcavi P, di PP, Lucchini G, Zanlari L, Passeri G, Zanni F, Chezzi C, Franceschi C, Sansoni P: Different contribution of EBV and CMV infections in very long-term carriers to age-related alterations of CD8+ T cells. Exp Gerontol 2004, 39:1233-1243.

42. Vescovini R, Biasini C, Fagnoni FF, Telera AR, Zanlari L, Pedrazzoni M, Bucci L, Monti D, Medici MC, Chezzi C, Franceschi C, Sansoni P: Massive load of functional effector CD4+ and CD8+ T cells against cytomegalovirus in very old subjects. J Immunol 2007, 179:4283-4291.

43. Miller JP, Allman D: The decline in B lymphopoiesis in aged mice reflects loss of very early B-lineage precursors. J Immunol 2003, 171:2326-2330.

44. Kline $\mathrm{GH}$, Hayden TA, Klinman NR: B cell maintenance in aged mice reflects both increased $B$ cell longevity and decreased $B$ cell generation. J Immunol 1999, 162:3342-3349.

45. Johnson KM, Owen K, Witte PL: Aging and developmental transitions in the B cell lineage. Int Immunol 2002, 14:1313-1323.

46. Cancro MP, Smith SH: Peripheral B cell selection and homeostasis Immunol Res 2003, 27:141-148.

47. Szabo P, Shen S, Telford W, Weksler ME: Impaired rearrangement of IgH V to DJ segments in bone marrow Pro-B cells from old mice. Cell Immunol 2003, 222:78-87.

48. Frasca D, Nguyen D, Riley RL, Blomberg BB: Decreased E12 and/or E47 transcription factor activity in the bone marrow as well as in the spleen of aged mice. J Immunol 2003, 170:719-726.

49. King AM, Keating $P$, Prabhu A, Blomberg BB, Riley RL NK cells in the CD19$B 220+$ bone marrow fraction are increased in senescence and reduce E2A and surrogate light chain proteins in B cell precursors. Mech Ageing Dev 2009, 130:384-392.

50. Fagnoni FF, Vescovini $R$, Mazzola M, Bologna G, Nigro E, Lavagetto G, Franceschi C, Passeri M, Sansoni P: Expansion of cytotoxic CD8+. Immunology 1996, 88:501-507.

51. Baecher-Allan C, Wolf E, Hafler DA: Functional analysis of highly defined, FACS-isolated populations of human regulatory CD4+ CD25+ T cells. Clin Immunol 2005, 115:10-18.

52. Baecher-Allan C, Brown JA, Freeman GJ, Hafler DA: CD4+CD25high regulatory cells in human peripheral blood. J Immunol 2001 , 167:1245-1253.

53. Fontenot JD, Gavin MA, Rudensky AY: Foxp3 programs the development and function of CD4+CD25+ regulatory T cells. Nat Immunol 2003 4:330-336.

54. Wildin RS, Smyk-Pearson S, Filipovich AH: Clinical and molecular features of the immunodysregulation, polyendocrinopathy, enteropathy, $\mathrm{X}$ linked (IPEX) syndrome. J Med Genet 2002, 39:537-545.

55. Tsaknaridis L, Spencer L, Culbertson N, Hicks K, LaTocha D, Chou YK Whitham RH, Bakke A, Jones RE, Offner H, Bourdette DN, Vandenbark AA: Functional assay for human CD4+CD25+ Treg cells reveals an agedependent loss of suppressive activity. J Neurosci Res 2003, 74:296-308.

56. Bouman A, Schipper M, Heineman MJ, Faas MM: Gender difference in the non-specific and specific immune response in humans. Am J Reprod Immunol 2004, 52:19-26.

57. Giltay EJ, Fonk JC, von Blomberg BM, Drexhage HA, Schalkwijk C, Gooren LJ: In vivo effects of sex steroids on lymphocyte responsiveness and immunoglobulin levels in humans. J Clin Endocrinol Metab 2000, 85:1648-1657.

58. McCombe PA, Greer JM, Mackay IR: Sexual dimorphism in autoimmune disease. Curr Mol Med 2009, 9:1058-1079.

59. Ansar AS, Penhale WJ, Talal N: Sex hormones, immune responses, and autoimmune diseases. Mechanisms of sex hormone action. Am J Pathol 1985, 121:531-551.

60. Weinstein $Y$, Ran S, Segal S: Sex-associated differences in the regulation of immune responses controlled by the MHC of the mouse. J Immunol 1984, 132:656-661

61. Terres G, Morrison SL, Habicht GS: A quantitative difference in the immune response between male and female mice. Proc Soc Exp Biol Med 1968, 127:664-667.

62. Kongshavn PA, Bliss JQ: Sex differences in survival of $\mathrm{H}-2$ incompatible skin grafts in mice treated with antithymocyte serum. Nature 1970, 226:451. 
63. Santoli D, Trinchieri G, Zmijewski CM, Koprowski H: HLA-related control of spontaneous and antibody-dependent cell-mediated cytotoxic activity in humans. J Immunol 1976, 117:765-770.

64. Bebo BF Jr, Adlard K, Schuster JC, Unsicker L, Vandenbark AA, Offner H: Gender differences in protection from EAE induced by oral tolerance with a peptide analogue of MBP-Ac1-11. J Neurosci Res 1999, 55:432-440.

65. Lotter H, Jacobs T, Gaworski I, Tannich E: Sexual dimorphism in the control of amebic liver abscess in a mouse model of disease. Infect Immun 2006, 74:118-124.

66. Mock BA, Nacy CA: Hormonal modulation of sex differences in resistance to Leishmania major systemic infections. Infect Immun 1988, 56:3316-3319.

67. dos Santos CD, Toldo MP, do Prado Junior JC: Trypanosoma cruzi: the effects of dehydroepiandrosterone (DHEA) treatment during experimental infection. Acta Trop 2005, 95:109-115.

68. Olivetti G, Giordano G, Corradi D, Melissari M, Lagrasta C, Gambert SR, Anversa P: Gender differences and aging: effects on the human heart. J Am Coll Cardiol 1995, 26:1068-1079.

69. Cowell PE, Turetsky Bl, Gur RC, Grossman Rl, Shtasel DL, Gur RE: Sex differences in aging of the human frontal and temporal lobes. J Neurosci 1994, 14:4748-4755.

70. Kyo S, Takakura M, Kanaya T, Zhuo W, Fujimoto K, Nishio Y, Orimo A, Inoue M: Estrogen activates telomerase. Cancer Res 1999, 59:5917-5921.

71. Tower J: Sex-specific regulation of aging and apoptosis. Mech Ageing Dev 2006, 127:705-718

doi:10.1186/1742-4933-7-4

Cite this article as: Yan et al:: The effect of ageing on human

lymphocyte subsets: comparison of males and females. Immunity \& Ageing 2010 7:4

\section{Submit your next manuscript to BioMed Central and take full advantage of:}

- Convenient online submission

- Thorough peer review

- No space constraints or color figure charges

- Immediate publication on acceptance

- Inclusion in PubMed, CAS, Scopus and Google Scholar

- Research which is freely available for redistribution

Submit your manuscript at www.biomedcentral.com/submit 